\title{
ARTICLE
}

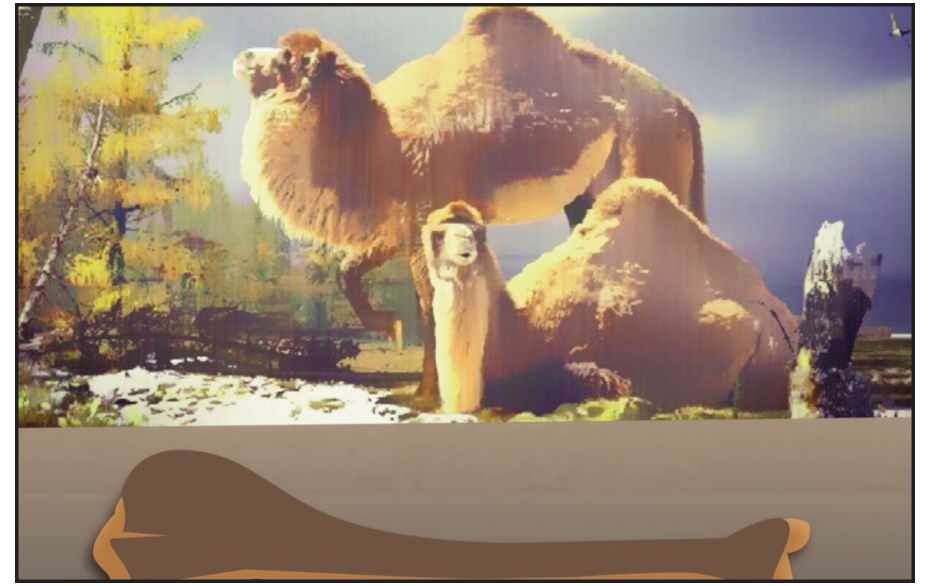

\section{PoLAR-FIT: Pliocene Landscapes and Arctic Remains-Frozen in Time}

J.C. Gosse ${ }^{1}$, A.P. Ballantyne ${ }^{2}$, J.D. Barker ${ }^{3,4}$, A.Z. Csank ${ }^{5}$, T.L. Fletcher ${ }^{2}$, G.W. Grant ${ }^{4}$, D.R. Greenwood ${ }^{6}$, R.D.E. $\mathrm{MacPhee}^{7}$ and N. Rybczynski ${ }^{8}$

'Department of Earth Sciences, Dalhousie University 1459 Oxford St, Halifax, Nova Scotia, B3H 4R2, Canada Email:john.gosse@dal.ca

${ }^{2}$ College of Forestry and Conservation, University of Montana 32 Campus Drive, Missoula, Montana, 59801, U.S.A.

${ }^{3}$ School of Earth Sciences, The Obio State University Marion, Ohio, 43302, U.S.A.

${ }^{4}$ Byrd Polar and Climate Research Centre Columbus, Ohio, 43210, U.S.A.

${ }^{5}$ Department of Geography at the University of Nevada Reno 1664 N Virginia Street, Reno, Nevada, 89557, U.S.A.

${ }^{6}$ Department of Biology, Brandon University $27018^{\text {th }}$ Street, Brandon, Manitoba, R7A 6A9, Canada

'Department of Mammalogy, Division of Vertebrate Zoology American Museum of Natural History,

Central Park. West at 79 th Street

New York, New York, 10024-5192, U.S.A.

${ }^{8}$ Canadian Museum of Nature

PO Box 3443, Station D, Ottawa, Ontario, K1P 6P4, Canada

\section{SUMMARY}

This short summary presents selected results of an ongoing investigation into the feedbacks that contribute to amplified Arctic warming. The consequences of warming for Arctic biodiversity and landscape response to global warmth are currently being interpreted. Arctic North American records of largescale landscape and paleoenvironmental change during the Pliocene are exquisitely preserved and locked in permafrost, providing an opportunity for paleoenvironmental and faunal reconstruction with unprecedented quality and resolution. During a period of mean global temperatures only $\sim 2.5^{\circ} \mathrm{C}$ above modern, the Pliocene molecular, isotopic, tree-ring, paleofaunal, and paleofloral records indicate that the High Arctic mean annual temperature was $11-19^{\circ} \mathrm{C}$ above modern values, pointing to a much shallower latitudinal temperature gradient than exists today. It appears that the intense Neogene warming caused thawing and weathering to liberate sediment and create a continuous and thick $(>2.5 \mathrm{~km}$ in places) clastic wedge, from at least Banks Island to Meighen Island, to form a coastal plain that provided a highway for camels and other mammals to migrate and evolve in the High Arctic. In this summary, we highlight the opportunities that exist for research on these and related topics with the PoLAR-FIT community.

\section{RÉSUMÉ}

Ce bref résumé présente les résultats choisis d'une enquête en cours sur les déclencheurs qui contribuent à l'amplification du réchauffement de l'Arctique. Les conséquences du réchauffement sur la biodiversité arctique et de la réponse du paysage au réchauffement climatique sont en cours d'être interprété. Des dossiers nord-américains de paysage à grande échelle et le changement paléoenvironnementales durant le Pliocène sont exceptionnellement préservés et scellées dans un état de congélation qui fournissant une occasion pour la reconstruction paléoenvironnementale et faunistique avec une qualité et une résolution sans précédent. Pendent une période de réchauffement global seulement $\sim 2,5^{\circ} \mathrm{C}$ au-dessus de moderne les dossiers, moléculaire, isotopique, annaux de croissance, paléofaunistique et paléovégétation indiquent que l'Arctique a connu une augmentation de la température annuelle moyenne de $11-19^{\circ} \mathrm{C}$ au-dessus de moderne, en montrant un inferieur gradient de température latitudinal qu'aujourd'hui. Il semble que le réchauffement intense pendent le Néogène a provoqué la décongélation et erosion pour libérer les sédiments et créer une plaine côtière continuel et épaisse $(>2,5 \mathrm{~km}$ dans lieux) qui a fourni une route pour les chameaux et autres mam- 


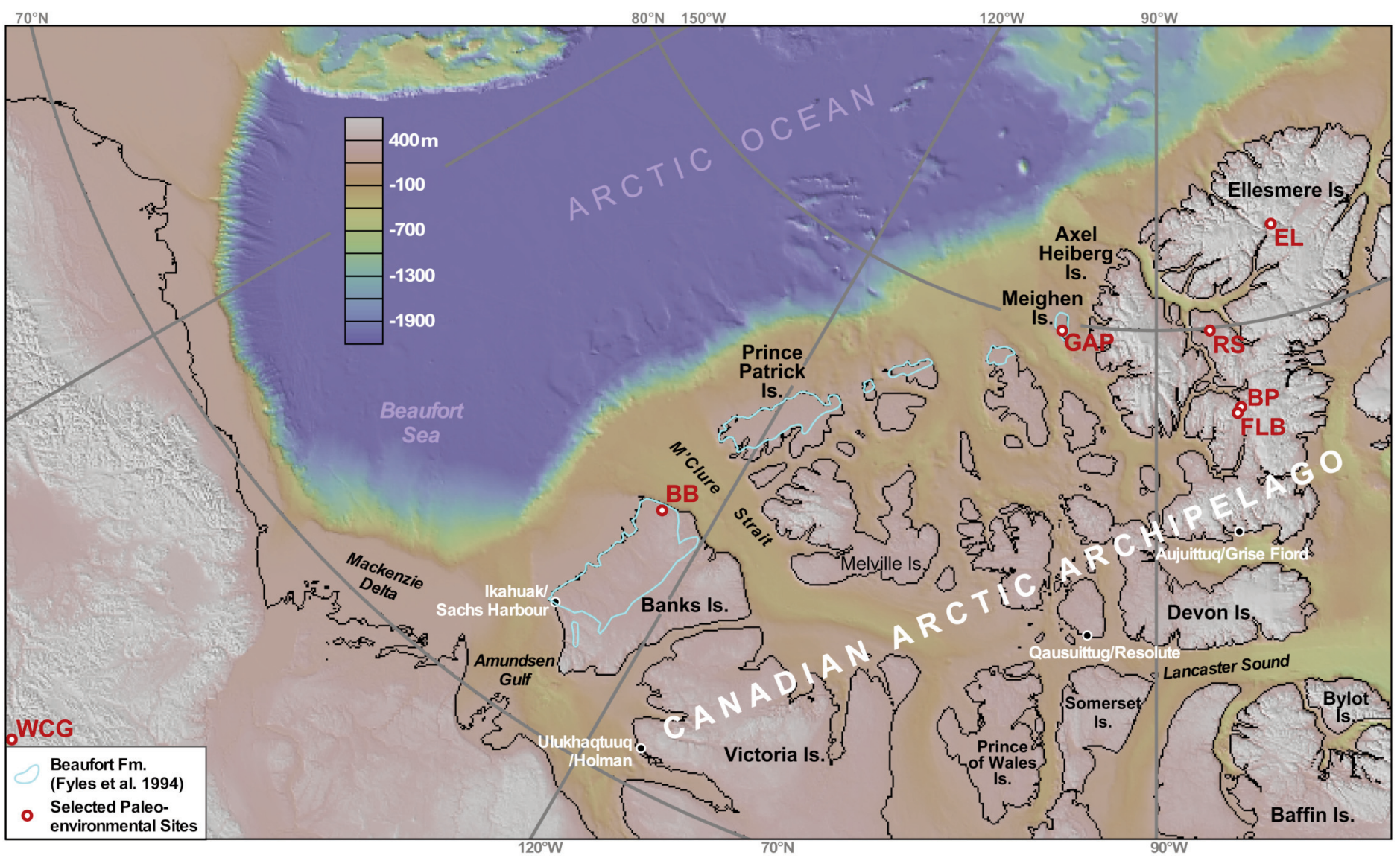

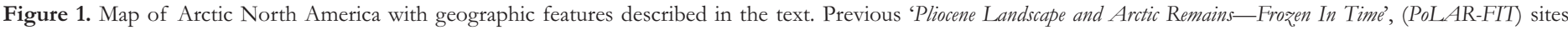

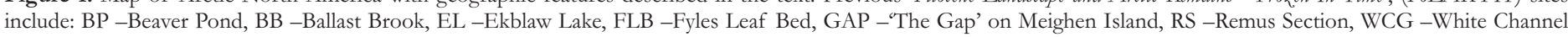

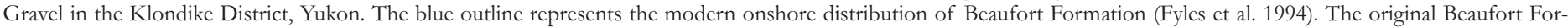

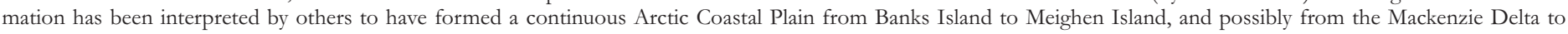

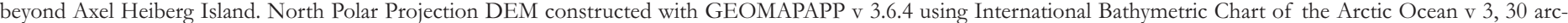
second resolution.

mifères pour migrer et évoluer dans l’Haut-Arctique. Dans ce résumé, nous soulignons les opportunités qui existent pour la recherche sur ces sujets et les sujets connexes avec la communauté PoLAR-FIT.

\section{INTRODUCTION}

Today's thawing of permanently frozen Pliocene clastic sediments and organic layers in Arctic Canada and Alaska (Fig. 1) provides access to exquisitely preserved, sub-fossilized floral, faunal, molecular, and isotopic records. These records document amplification of temperature change in polar regions (e.g. Ballantyne et al. 2013) during periods of global warmth on the magnitude predicted for our next century (Masson-Delmotte et al. 2013). The Pliocene sediments exposed onshore, including the Beaufort Formation, span a variety of depositional environments (marine, lacustrine, paludal, alluvial, fluvial, and possibly glacial) over a wide temporal range (ca. 3.8 to 2.6 Ma; see later discussion of Geochronology), including varves and possible annual couplets of sand and leaf layers spanning a millennium. Until recently (e.g. Feng et al. 2017) numerical models of Pliocene climate were unable to reproduce the high paleo-temperatures in the High Arctic while reli- ably replicating low-latitude temperature proxies (Salzmann et al. 2013). The collective record suggests that there may be feedbacks that are not adequately represented by the models. Temperature, humidity, $\mathrm{CO}_{2}$, and continentality may be controlled by factors such as different forest types and densities, sea-ice cover, the effects of forest fires, and the possibility that ocean circulation through the High Arctic was limited until the Beaufort Formation was incised and the Northwest Passages were opened. Despite the discovery of well-preserved wood by explorers on Banks Island 150 years ago (Heer 1868), the paleoenvironmental and paleoclimate research is still in its infancy and the biochronostratigraphy is too imprecise to test synchroneity and reconcile the disparities among the sites. Furthermore, accelerated processes such as retrogressive thaw slumping is rapidly removing or exposing previously entombed sedimentary, macrofossil, and biochemical records before they can be examined within their stratigraphic context.

To tackle these challenges, an international multidisciplinary team has assembled with the shared objective of studying these systems in an integrated way. The represented disciplines include paleoclimatology, geomorphology, geochronology, biogeochemistry, dendroclimatology, floral and faunal paleon- 
tology, evolutionary biology, and landscape ecology. Members of the 'Pliocene Landscape and Arctic Remains_-Frozen In Time', or PoLAR-FIT working group span from early-career to senior scientists, some of whom have worked on the Pliocene records over the past four decades (Table 1 lists the founding members, but we hope that others will join).

The initial goals of PoLAR-FIT are to maximize synergy, minimize the prohibitive costs of fieldwork in the Arctic, and expedite progress toward common research objectives that will have the immediate and broadest impact on the global community. This article provides a short review and outline of past and planned PoLAR-FIT research and highlights the many opportunities for other scientists to contribute and join.

\section{PROGRESS IN PLIOCENE ARCTIC PALEO-ENVIRONMENTAL RESEARCH}

\section{The Floral Record}

The Pliocene Arctic and sub-Arctic were characterized by both a more northerly position of the tree line compared to today (e.g. the limit was $\sim 80^{\circ} \mathrm{N}$ on Meighen Island, compared to $\sim 69-61^{\circ} \mathrm{N}$ in the western Arctic or $56^{\circ} \mathrm{N}$ in Labrador [e.g. Tozer and Thorsteinsson 1964; Hills 1975; Matthews 1987; Fyles et al. 1991]) and, consequently, a broader latitudinal extent of the Boreal zone. Based on pollen and plant macrofossils a flora more diverse than a modern boreal forest was found for the Pliocene units, including 80-90 species of nonvascular plants and 90 different species of vascular plants. The taxonomic and comparative studies of these flora represent a substantial legacy inherited by the group (e.g. Matthews and Ovenden 1990; Matthews and Fyles 2000; Fletcher et al. 2017). Included in this list are 12 different tree taxa identified from leaves or reproductive parts including, larch (Larix), birch (Betula), spruce (Picea), hemlock (Tsuga), pine (Pinus), alder (Alnus), poplar (Populus), and fir (Abies) (e.g. Matthews and Ovenden 1990; Ballantyne et al. 2010). Wood found in many of the fossil forest sites has been identified as larch (Larix), spruce (Picea), pine (Pinus) and birch (Betula) (e.g. Matthews and Ovenden 1990; Csank et al. 2011a). Based on plant abundances Matthews and Ovenden (1990) concluded that the flora is closely similar to modern Asian forests rather than to a typical North American boreal forest, and more recent workers support this conclusion (Ballantyne et al. 2010; Csank et al. 2011a). Elements of modern-character tundra communities were also already in place both within boreal communities, and potentially at higher latitudes (Matthews and Ovenden 1990; Matthews and Fyles 2000). The woody elements of the flora are conspicuously well preserved in some areas (Devaney 1991; Davies et al. 2013) (Fig. 2) and present a rare but significant opportunity to construct overlapping annual sequences with tree ring records (e.g. Csank et al. 2013). Extensive peat deposits (Mitchell et al. 2016) record long, environmentally sensitive floral sequences from pollen, seeds, needles, cones, leaves (Fig. 3), flowers, and mosses. The flora can often be identified to modern genera and in some cases species, permitting precise climate and vegetation reconstructions (e.g. Ballantyne et al. 2010). In addition, these same deposits preserve fau-
Table 1. Founding PoLAR-FIT members.

\begin{tabular}{ll}
\hline \hline Ballantyne, A. & University of Montana \\
Barendregt, R. & Lethbridge University \\
Barker, J. & Byrd Polar and Climate Research Centre \\
Braschi, L. & Dalhousie University \\
Brigham-Grette, J. & University of Massachusetts \\
Csank, A. & University Nevada, Reno \\
Fletcher, T. & University of Montana \\
Fortier, D. & University of Montreal \\
Froese, D. & University of Alberta \\
Gilbert, M. & Canadian Museum of Nature \\
Gosse, J. & Dalhousie University \\
Grant, G. & Byrd Polar and Climate Research Centre \\
Greenwood, D. & Brandon University \\
Harington, C.R. & Canadian Museum of Nature (Emeritus) \\
Lakeman, T. & Norwegian Geological Survey \\
Manion, P. & Dalhousie University \\
Matthews, J. & Geological Survey of Canada (Retired) \\
McPhee, R. & American Museum of Natural History \\
Rybczynski, N. & Canadian Museum of Nature; Carleton University \\
Smith, R. & University of Calgary \\
Telka, A. & Paleotec Services \\
West, C. & University of Saskatchewan \\
Zazula, G. & Yukon Geological Survey \\
\hline
\end{tabular}

nal remains ranging from terrestrial (e.g. beetles) and aquatic invertebrates (e.g. Fyles et al. 1991; Elias and Matthews 2002) to the vertebrate inhabitants of these Arctic forests (e.g. Rybczynski et al. 2013).

\section{Vertebrate Paleontology}

Currently, the record of Pliocene vertebrates from the High Arctic is known almost entirely from sites on Ellesmere Island, notably the Beaver Pond site (Fig. 1) near the head of Strathcona Fiord. Elsewhere, isolated bone fragments of possible Pliocene age have been found on Banks Island (by the coauthors in 2013) and Meighen Island (by the co-authors in 2010) but remain under investigation (Fig. 1). Decades of field excavations from Beaver Pond have yielded a boreal forest community with no modern analogue. The assemblage is more diverse than modern treeline communities and includes fossil bear, horse, deerlet, rabbit, various small carnivores, shrew, beaver, fish, scaup duck and frog (Tedford and Harington 2003; Mitchell et al. 2016). Many fossils from the site represent new taxa, including the fish (Sander taneri), badger (Arctomeles sotnikovae), shrew (Arctisorex polaris), and deerlet (Boreameryx braskerudi) (Hutchison and Harington 2002; Tedford and Harington 2003; Dawson and Harington 2007; Murray et al. 2009). The deerlet is notable because it appears to be derived from an early branch of the deer lineage; however, its dentition is highly specialized, suggesting high latitude endemism.

Owing to the geographical remoteness of Ellesmere Island (Fig. 1) and its Pliocene fossils, the closest fossil communities of similar age available for comparisons are in Northeastern China and Idaho. Most taxa, such as the badger and horse (Plesiobipparion) show closest affinities to Pliocene fossil vertebrates of the Yushe Basin, China, whereas the rabbit (Hypolagus) and $\operatorname{dog}$ (Eucyon) represent lineages that originated in 


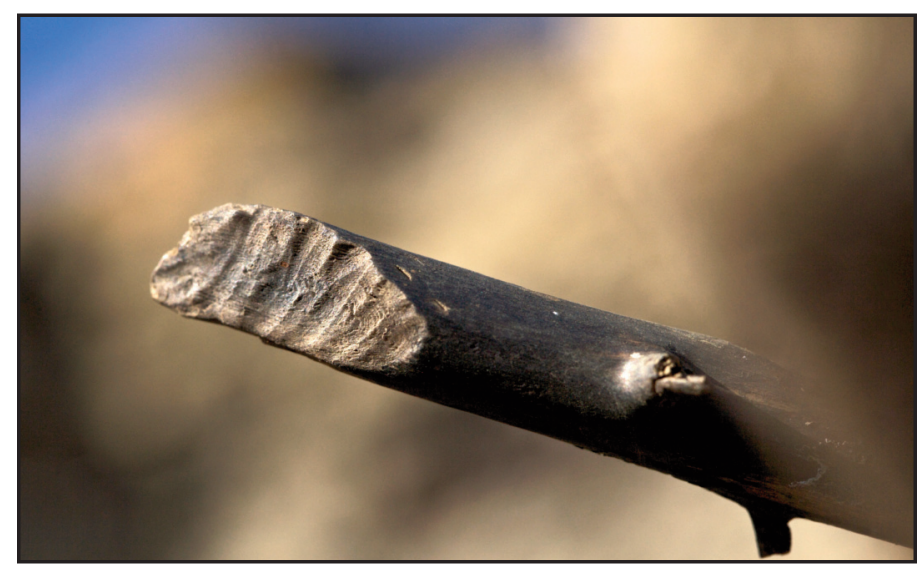

Figure 2. A sub-fossil stick, long held in permafrost, exposes at its end the characteristic cut-marks made by the lower front teeth of the Pliocene beaver Dipoides sp. (photo credit: M. Lipman).

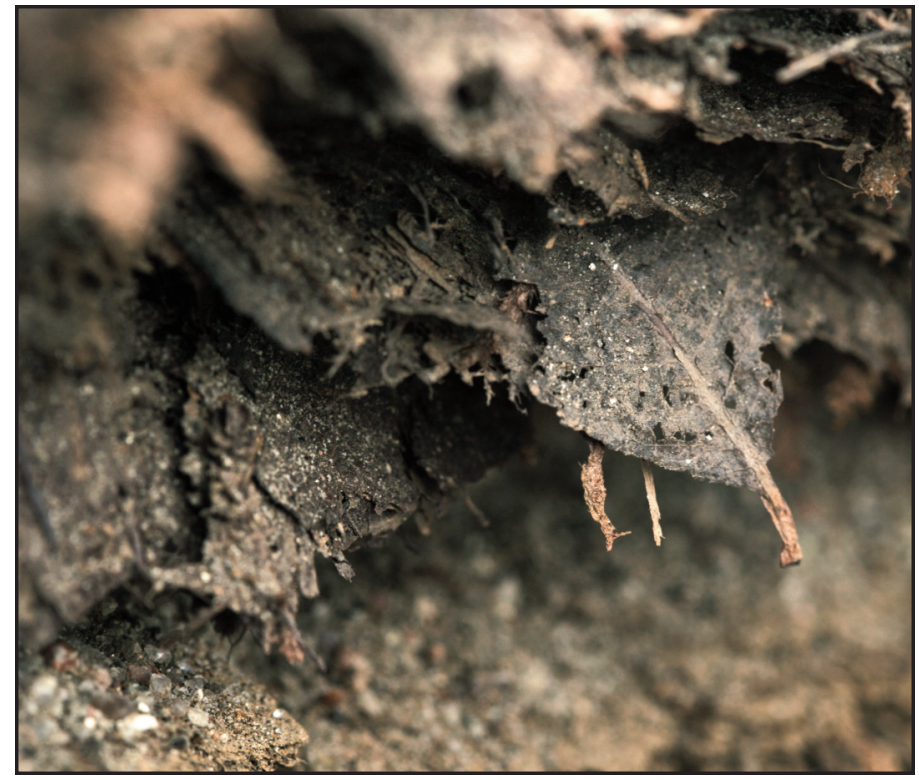

Figure 3. An ancient leaf protrudes from the slope where the enclosing sands have eroded as the permafrost face thaws (photo credit: M. Lipman).

North America. The Beaver Pond bear represents a species ("Ursus" abstrusus) also collected in Idaho, although the lineage originates in Eurasia (Tedford and Harington 2003). In recent years, fragments of fossil bone (Fig. 4) collected from the nearby Fyles Leaf Bed site belong to a giant camel, possibly Paracamelus, of North American lineage (Rybczynski et al. 2013) (Fig. 5). Significantly, taxonomic identification of the bone fragments as camel was aided by collagen fingerprinting. The discovery that these $3.5 \mathrm{Ma}$ fossils preserve collagen, a structural protein that makes up about $80 \%$ of the organic fraction of mammal bones is remarkable, providing a foundation for future ecological and taxonomic investigations.

\section{Sedimentary Records of Landscape Responses to Climate Change}

The Pliocene records described above were recovered from onshore exposures of the Beaufort Formation (from Banks

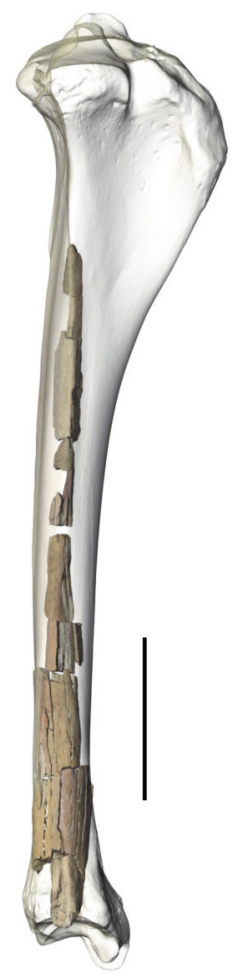

Figure 4. Fossil remains of an Arctic giant camel - lateral view of right tibia specimen (NUFV 210), from Fyles Leaf Bed (FLB) site, Strathcona Fiord (Ellesmere Island), shown within the tibia of a modern camel (Camelus dromedaries, ROM MAM 94191). The modern Camelus tibia has been scaled up 30\% to match the size of the fossil tibia. Scale bar, $10 \mathrm{~cm}$. (From Rybczynski et al. 2013: figure 3).

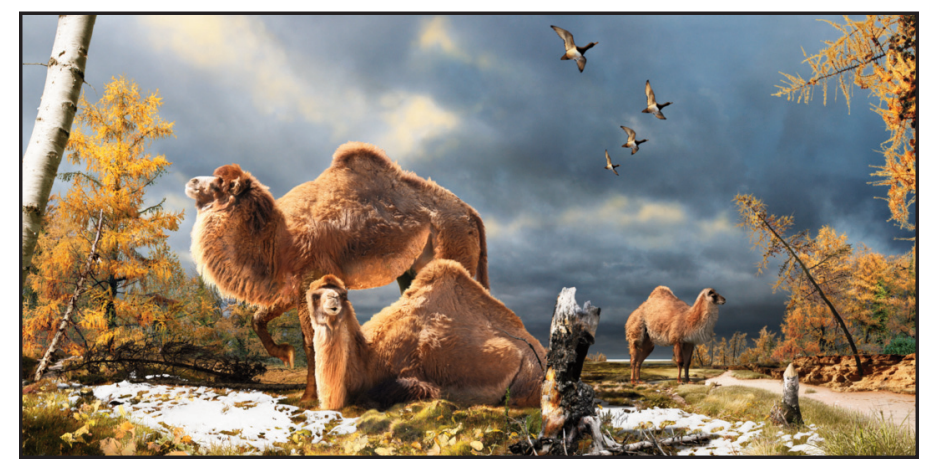

Figure 5. Mid-Pliocene camels prepare for the long dark winter along a shallow river channel in a beaver-cut larch and birch-dominated taiga forest, $100 \mathrm{~km}$ southeast of what is now the Eureka weather station, Ellesmere Island (digital image, J. Csotonyi)

Island to Meighen Island) or correlative deposits (e.g. on Ellesmere Island). Previous and ongoing efforts have focused on characterizing the depositional environments that contain the organic remains. The Beaufort Formation was originally described by Tozer (1956) but most recently defined by Fyles et al. (1994) as outcrops along the western Canadian Arctic Archipelago (Fig. 1). The Beaufort Formation formed the Arctic Coastal Plain (e.g. Devaney 1991) which is the uppermost unit of the Arctic Continental Terrace Wedge (Trettin 1989). The braided-stream deposit extends into a thick (up to $3 \mathrm{~km}$ ) clastic wedge offshore. The marine extension of the clastic 
wedge is the Iperk Formation and estuarine sediments are recognized onshore in the Beaufort Formation (England 1987; Fyles 1990; McNeil et al. 2001). Fyles et al. (1994) and others before documented sites at other locations, such as high terraces and alluvial fans throughout Ellesmere Island, which have a similar age and faunal and floral record, but a different depositional environment from the braided stream coastal plain Beaufort Formation sediments. The various depositional environments inform the paleoenvironmental reconstruction and the sedimentary architectural elements provide a sense of duration at single exposures. For instance, at the base of the Fyles Leaf Bed section (Fig. 1), varved lake sediments containing dropstones underlie hundreds of rhythmic beds of sandleaf layer couplets interpreted to represent shallow overbank and crevasse splay deposits adjacent to a distributary sandy braided-stream system. The possible annularity of those beds is being investigated and could potentially be exploited to reveal the frequency of forest fires and other climatogenic events. Cross-bedded woody detritus (Davies et al. 2013) is an example of a sedimentary structure apparently unique to a Pliocene forested fluvial environment with long dark and subzero winters. The emerging chronostratigraphy seems to indicate that much of the Beaufort Formation, and perhaps regional correlatives (e.g. parts of the offshore Iperk Formation, the White Channel Gravel in Yukon (Fig. 1), and various high terraces and alluvial fans on Axel Heiberg and Ellesmere Islands), were deposited over a very short time period between about 3.8 to $2.6 \mathrm{Ma}$, spanning the Pliocene-Pleistocene climate transition.

If the mapped units of Beaufort Formation on each western island of the archipelago were part of a continuous coastal plain, then the Northwest Passages (e.g. M'Clure Strait, Fig. 1) may not have existed in the Pliocene. The absence of the Northwest Passages prior to the Quaternary has been considered since Tozer (1956) but not proven. However, ongoing research to evaluate the regional lithospheric flexural response to their excavation reveals that the topography of the islands is consistent with post-Beaufort Formation (i.e. Quaternary) excavation (Manion 2017). The subsequent drop in relative sea level with Pleistocene cooling likely caused fluvial incision initially, followed by glacial deepening under the Innuitian and Laurentide Ice Sheets. It also appears that lithospheric flexure by loading of the Neogene clastic wedge may have partly controlled the ribbon-like distribution of the mapped Beaufort Formation by providing accommodation space with (albeit low amplitude) flexural bulge parallel but inland of the western coast line (Manion 2017). Acquisition and interpretation of high resolution seismic reflection data throughout the Northwest Passages is needed to fully address the timing and evolution of the Northwest Passages.

We now are attempting to quantify the rates of sedimentation throughout the Beaufort Formation and correlative units such as the White Channel Gravel of the Klondike Gold District. Abundances of cosmogenic nuclides in quartz grains reflect duration of their exposure to cosmic radiation, decay duration during burial, and erosion rate of the exposed surface. In every sample, hundreds of thousands of quartz sand grains record the erosion rate from different locations throughout a Pliocene catchment and allow us to evaluate the spatial and temporal variability in catchment average paleoerosion rates. The results allow us to test landscape responses to climate change, such as the possibility that weathering before and during the mid-Pliocene warm period may have provided an easily accessed source of quartz-rich sand to form the Beaufort Formation clastic wedge (up to $3 \mathrm{~km}$ thick in places) during the Pliocene-Pleistocene transition.

\section{Paleoclimate Indices}

There is broad interest in the Pliocene as a deep-time laboratory for understanding near-future climate. The ages of the localities studied by this workgroup span 3.8-2.6 Ma covering a large portion of the Pliocene. These sediments would have recorded paleoclimate during the warm periods of the Pliocene, and the transition into cooler climates involving large-scale Northern Hemisphere glaciation. Overlain on this trend are damped periodicities which have been detected and are linked to obliquity and processional cycles (e.g. Draut et al. 2003) and variability in atmospheric $\mathrm{CO}_{2}$ (Seki et al. 2010; Pagani et al. 2010; Martínez-Botí et al. 2015). Nested within the broader period considered by PoLAR-FIT, the midPliocene warm period ( $m P W P ; 3.29-2.97 \mathrm{Ma}$ ), has received the greatest attention in the literature as the time slice for the longrunning Pliocene Research Interpretation and Synoptic Mapping (PRISM) project. The $m P W P$ was defined on the basis of a recognizably high global temperature and the convenience of magnetostratigraphic boundaries (Haywood et al. 2009). Shorter time slices (e.g. 3.264-3.025 Ma) provide foci for the other studies (e.g. Pliocene Model Intercomparison Projects (PlioMIP), Haywood et al. 2009). The time recorded at our terrestrial localities is much broader, as are our uncertainties (see Geochronology) and thus precise correlation with the $m P W P$ is not yet possible. Improving the precision and quantity of terrestrial observations of climate is currently a critical goal for providing data against which climate models may be verified.

The high-quality preservation of multiple proxies available from the sites currently investigated by PoLAR-FIT allows for the simultaneous reconstruction of paleoclimate and paleoenvironment from a single site. For example, we can determine atmospheric $\mathrm{CO}_{2}$, air temperature, and water temperature all at the same locality. Terrestrial climate proxies used at the High Arctic sites so far include mutual range methods on the beetle fauna (Elias and Matthews 2002) and flora (Ballantyne et al. 2010), dendroclimatologic and isotopic approaches using tree rings (Ballantyne et al. 2006, 2010; Csank et al. 2011a), 'clumped isotopes' (i.e. using molecules of similar chemical composition but different isotopic composition) analysis of freshwater molluscs (Csank et al. 2011b), and bacterial tetraether analysis (Ballantyne et al. 2010) (Fig. 6). There is also potential for investigation using foliar physiognomic methods (e.g. variation in leaf margin attributes, cf. CLAMP: Yang et al. 2011), mutual climatic range methods with improvements to the statistical framework (e.g. CRACLE; Harbert and Nixon 2015), leaf stomatal methods to determine coeval $\mathrm{CO}_{2}$ (RothNebelsick 2005), and biogeochemical potential via functional 


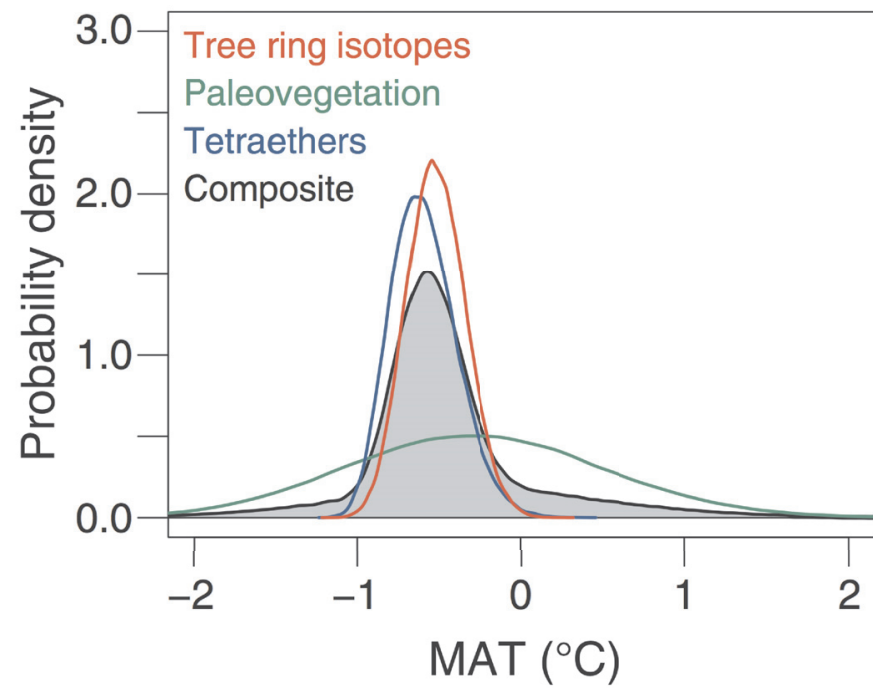

Figure 6. Using multiple proxies for paleoclimate analysis. Probability density functions of mean annual temperature (MAT) estimates for the Arctic during the Pliocene based on three independent proxies. Plotted are the three bootstrapped estimates of MAT derived from our three proxies (coloured lines) and the density function for the composite estimate of MAT derived from resampling the joint distribution across all three independent proxies (grey-filled; from Ballantyne et al. 2010: figure 2).

microbial genes (Xue et al. 2016). The group also is attempting to crossdate multiple in situ logs containing one or more burn scars to assist in the assessment of fire frequency. Some logs have over 200 tree rings.

\section{Geochronology}

The fossil-rich Beaufort Formation and correlative sediments have been dated with a combination of biostratigraphy, magnetostratigraphy, and numerical methods including cosmogenic ${ }^{26} \mathrm{Al} /{ }^{10} \mathrm{Be}$ burial and isochron methods on quartz sand, and amino acid racemization (AAR) and $\mathrm{Sr}$ isotope dating of marine shells (Mya truncata and Hiatella arctica). At Meighen Island (Fig. 1), AAR (>2.4 $\pm 0.5 \mathrm{Ma})$ and $\mathrm{Sr}(2.8-5.1 \mathrm{Ma})$ results (Brigham-Grette and Carter 1992) support the marine and terrestrial biostratigraphy. In the Klondike Gold District of Yukon, cosmogenic nuclide burial ages (Hidy et al. 2013) have confirmed the interpretation of magneto- and biostratigraphy pinned with tephrochronology using fission track dating of volcanic glass (Preece et al. 2011). Their burial age 2.64 $+0.20 /-0.18 \mathrm{Ma}$ ( $1 \sigma$ total external error; now $2.84 \mathrm{Ma}$ adjusted for updates in cosmogenic nuclide production rates) for the top portion of the Upper White Channel Gravel dates the first Cordilleran Ice Sheet and provides a maximum age for the top of the White Channel Gravel (Fig. 1). As in the Yukon, the goal is to anchor paleomagnetic stratigraphy at sites throughout the Beaufort Formation to utilize the precision of the timing of polar reversals. Cosmogenic nuclide burial dating at the Beaver Pond Site (Fig. 1) yielding 3.4 +0.6/-0.4 Ma was interpreted as a minimum age for the Beaver Pond owing to the possibility of post-depositional production of the isotopes by deeply penetrating muons (Rybczynski et al. 2013). Twenty kilometres from the Beaver Pond, minimum burial ages of 3.8 $+1.0 /-0.7 \mathrm{Ma}$ were reported for the Fyles Leaf Bed site (Fig.
1; Rybczynski et al. 2013). Additional samples have since been collected to improve on the precision of these sites, and unpublished and tentative ages have been measured at Meighen Island, Banks Island, and the Remus site on Ellesmere Island. Moving forward, PoLAR-FIT will use the ${ }^{26} \mathrm{Al} /{ }^{10} \mathrm{Be}$ burial and isochron methods at sites with key fossil or environmental records, where sediments are sufficiently thick to minimize the effect of post-depositional production by cosmic ray secondaries. However, to improve on the cosmogenic nuclide burial dating we will continue to further develop magnetostratigraphy where possible (e.g. Fyles et al. 1991). PoLARFIT will continue to collaborate with other researchers (including the Geological Survey of Canada and international groups) to build on this Arctic chronostratigraphy. The cosmogenic nuclide results also yield paleo-erosion rates, which provide insight into the variation in sedimentation rates during the climate transition.

\section{EXAMPLES OF HYPOTHESES}

The PoLAR-FIT workgroup has prioritized topics and hypotheses for testing initially, as follows:

(i) That Arctic forest processes, including forest fires, may be important feedbacks to polar amplification of temperature.

(ii) The 'regolith hypothesis,' that a thick saprolite or regolith was generated during the mid-Pliocene and stripped rapidly during the Pliocene-Pleistocene transition.

(iii) That the Northwest Passages were last opened after 2.7 $\mathrm{Ma}$ ago, beginning with fluvial incision in response to Pleistocene sea-level fall, and continuing with glacial erosion which widened and deepened the straits and sounds.

(iv) Consequently, we also hypothesize that the terrestrial distribution of the Beaufort Formation is tied to loadinginduced lithospheric flexure and that unloading during excavation of the Northwest Passages may have caused strata and topography to experience uplift along the coasts of the straits.

(v) That records of summer temperature may provide insight into the nature of sea ice cover during the Pliocene.

(vi) The closest fossil relatives of the known High Arctic Pliocene flora and fauna are in mid-continental western North America and the Yushe Basin, China.

(vii) We hypothesize from biogeographical and phylogenetic evidence that an extensive, diverse polar Neogene forest biome existed in the warm part of the Pliocene, spanning Eurasia and northern North America. We will test this by searching for additional confirmatory fossil evidence in future field seasons.

\section{POLAR-FIT RESEARCH OBJECTIVES}

The long-term research objectives of PoLAR-FIT are:

1. To understand the interaction of climate and landscape change and how this has affected the evolution and migration of organisms through the Western Arctic during the Pliocene.

2. To understand factors underlying Pliocene floral and faunal 
diversity, and the role of the Neogene Arctic in patterning modern biodiversity.

3. Identify and quantify proxies of climatic and environmental conditions in the Pliocene Arctic that improve our understanding of ecological processes and climate interactions at high latitudes during periods of global warmth.

4. To develop a conceptual model, supported by sedimentology and stratigraphy, lithospheric flexure modelling, paleoecology, and paleoclimatology that captures the landscape evolution of the Canadian Arctic Archipelago since the middle Pliocene.

The short-term (5-10 year) research goals are:

1. To identify additional Pliocene sites, with well-constrained ages, to improve data-model comparisons for warm period climate modelling.

2. To build a Pliocene annual time series by crossdating fossil wood and to investigate whether multiple proxies derived from fossil tree rings can be used to characterize the annual and seasonal climate of the Arctic and understand its impacts on ecosystem dynamics.

3. To investigate the impact of currently hypothesized terrestrial feedbacks to polar amplification through climate and atmospheric proxies, and environmental and paleoecological reconstruction at key sites, and integration with current climate modelling.

4. To discover and describe Pliocene High Arctic vertebrate species, using morphological and proteomic techniques.

5. To enrich the faunal, floral, and paleoenvironmental proxy interpretations with improved chronostratigraphy and to investigate the archipelago-scale landscape evolution during the Pliocene-Pleistocene transition.

\section{Targeted Sites}

The Beaufort Formation has been recognized on all western Arctic Canada islands, from Banks Island to Meighen Island (Fig. 1). Correlative records have been studied at multiple sites throughout Ellesmere Island, and mid- to late-Pliocene fossil tree fragments on Axel Heiberg and Bylot Island (Fig. 1) have been studied (e.g. Csank et al. 2013), although the stratigraphy there needs further analysis and improved confidence for dating. Offshore, seismic and well data, and core samples from the Iperk Formation are being analyzed to help establish the timing of the post-Miocene transgression and other unconformities, and to separate Pleistocene and Holocene deposits from the Pliocene (Lakeman et al. 2014). With new tools, we are improving the bio- and chrono-stratigraphic correlation of new and existing Pliocene sections such as the White Channel Gravel (Fig. 1) and other well-studied records in western Yukon and northern Alaska. Unlike older and more resilient lithified records, most of these Pliocene beds may have survived only because of permafrost. While retrogressive thaw slumps, solifluction, and other gravitational erosion continue to rejuvenate and expose new records in unconsolidated sands - motivating revisits - key records at some locations are unlikely to survive decades. The next major target, planned for 2017, will be dozens of sections exposed on Prince Patrick
Island, where the Beaufort Formation was first described by Tozer (1956).

\section{ACKNOWLEDGEMENTS}

PoLAR-FIT is grateful for the outstanding logistic support provided throughout the Canadian Arctic by the Polar Continental Shelf Program and in-kind support for accessing these sites. Without their professionalism and efficiency, our discoveries and knowledge growth could not be possible. We also thank the Canadian Museum of Nature for the past and recent support of critical research and meeting space, field equipment, and funding for research by members of their Arctic program. PoLAR-FIT members have benefited from financial support from Natural Science and Engineering Research Council of Canada Discovery Grant Program and NSERC-Northern Research Supplement Program, and the USA National Science Foundation. Special thanks to W. Garfield Weston Foundation for funding NR, a Post-doctoral Fellowship to TL, and a Graduate Student Fellowship to a past student; the National Geographic Society, who have provided field funding for NR and TF; and Byrd Polar and Climate Research Centre, Ohio State University Office of International Affairs, Geologic Society of America, the Columbus Rock and Mineral Society and the individual donors for their field funding for GG. Most significantly, we thank the northern hamlets of Resolute Bay (Qausuittuq), Grise Fiord (Aujuittuq), Sachs Harbour (Ikahuak), and Holman (Ulukhaqtuuq) and their Hunting and Trapping Committees for supporting our research over the past two decades. We hope past and future PoLAR-FIT landscape and climate research will be directly useful to their communities. We thank D. Froese for comments that improved an earlier version of this manuscript, and T. Bell, J. England, and A. Kerr for reviews which significantly improved its readability.

\section{REFERENCES}

Ballantyne, A.P., Rybczynski, N., Baker, P.A., Harington, C.R., and White, D., 2006, Pliocene Arctic temperature constraints from the growth rings and isotopic composition of fossil larch: Palaeogeography, Palaeoclimatology, Palaeoecology, v. 242, p. 188-200, https://doi.org/10.1016/j.palaeo.2006.05.016.

Ballantyne, A., Greenwood, D. Damsté, J., Csank, A., Eberle, J., and Rybczynski, N., 2010, Significantly warmer Arctic surface temperatures during the Pliocene indicated by multiple independent proxies: Geology, v. 38, p. 603-606, https://doi.org/10.1130/G30815.1.

Ballantyne, A.P., Axford, Y., Miller, G.H., Otto-Bliesner, B.L., Rosenbloom, N., and White, J.W.C., 2013, The amplification of Arctic terrestrial surface temperatures by reduced sea-ice extent during the Pliocene: Palaeogeography, Palaeoclimatology, Palaeoecology, v. 386, p 59-67, https://doi.org/10.1016/ j.palaeo.2013.05.002.

Brigham-Grette, J., and Carter, L.D., 1992, Pliocene marine transgressions of Northern Alaska: Circumarctic correlations and paleoclimatic interpretations: Arctic, v. 45, p. 75-89, https://doi.org/10.14430/arctic1375.

Csank, A.Z., Patterson, W.P., Eglington, B.M., Rybczynski, N., and Basinger, J.F., 2011a, Climate variability in the Early Pliocene Arctic: Annually resolved evidence from stable isotope values of sub-fossil wood, Ellesmere Island, Canada: Palaeogeography, Palaeoclimatology, Palaeoecology, v. 308, p. 339-349, https://doi.org/10.1016/j.palaeo.2011.05.038.

Csank, A.Z., Tripati, A.K., Patterson, W.P., Eagle, R.A., Rybczynski, N., Ballantyne, A.P., and Eiler, J.M., 2011b, Estimates of Arctic land surface temperatures during the early Pliocene from two novel proxies: Earth and Planetary Science Letters, v. 304, p. 291-299, https://doi.org/10.1016/j.epsl.2011.02.030.

Csank, A.Z., Fortier, D., and Leavitt, S.W., 2013, Annually resolved temperature reconstructions from a late Pliocene-early Pleistocene polar forest on Bylot Island, Canada: Palaeogeography, Palaeoclimatology, Palaeoecology, v. 369, p. 313-322, https://doi.org/10.1016/j.palaeo.2012.10.040.

Davies, N., Gosse, J., and Rybczynski, N., 2014, Cross-bedded woody debris from a Pliocene forested river system in the High Arctic: Beaufort Formation, Meighen Island, Canada: Journal of Sedimentary Research, v. 84, p. 19-25, https://doi.org/10.2110/jsr.2014.5.

Dawson, M.R., and Harington, C.R., 2007, Boreameryx, an unusual new artiodactyl (Mammalia) from the Pliocene of Arctic Canada and endemism in Arctic fossil mammals: Canadian Journal of Earth Sciences, v. 44, p. 585-592, https://doi.org/ 10.1139/e06-111.

Devaney, J.R., 1991, Clastic sedimentology of the Beaufort Formation, Prince Patrick Island, Canadian Arctic Islands: Late Tertiary sandy braided river deposits with woody detritus beds: Arctic, v. 44, p. 206-216, https://doi.org/ $10.14430 /$ arctic1540.

Draut, A.E., Raymo, M.E., McManus, J.F., and Oppo, D.W., 2003, Climate stability during the Pliocene warm period: Paleoceanography, v. 18, p. 1-12, 
https://doi.org/10.1029/2003PA000889.

Elias, S.A., and Matthews Jr., J.V., 2002, Arctic North American seasonal temperatures from the latest Miocene to the Early Pleistocene, based on mutual climatic range analysis of fossil beetle assemblages: Canadian Journal of Earth Sciences, v. 39, p. 911-920, https://doi.org/10.1139/e01-096.

England, J., 1987, Glaciation and the evolution of the Canadian High Arctic landscape: Geology, v. 15, p. 419-424, https://doi.org/10.1130/0091-7613(1987)15 $<419$ :GATEOT>2.0.CO;2.

Feng, R., Otto-Bliesner, B.L., Fletcher, T.L., Tabor, C.R., Ballantyne, A.P., and Brady E.C., 2017, Amplified Late Pliocene terrestrial warmth in northern high latitudes from greater radiative forcing and closed Arctic Ocean gateways: Earth and Planetary Science Letters, v. 466, p.129-138, https://doi.org/10.1016/ j.epsl.2017.03.006.

Fletcher, T., Feng, R., Telka, A.M., Matthews Jr., J.V., and Ballantyne, A., 2017, Floral dissimilarity and the influence of climate in the Pliocene High Arctic: Biotic and abiotic influences on five sites on the Canadian Arctic Archipelago: Frontiers in Ecology and Evolution, v. 5, Article 19, https://doi.org/10.3389/ fevo.2017.00019.

Fyles, J.G., 1990, Beaufort Formation (Late Tertiary) as seen from Prince Patrick Island, Arctic Canada: Arctic, v. 43, p. 393-403, https://doi.org/10.14430/arctic1632.

Fyles, J.G., Marincovich Jr., L., Matthews Jr., J.V., and Barendregt, R., 1991, Unique mollusc find in the Beaufort Formation (Pliocene) on Meighen Island, Arctic Canada: Geological Survey of Canada - Current Research B, v. 91, p. 105-112.

Fyles, J.G., Hills, L.V., Matthews Jr., J.V., Barendregt, R., Baker, J., Irving, E., and Jetté, H., 1994, Ballast Brook and Beaufort formations (Late Tertiary) on Northern Banks Island, Arctic Canada: Quaternary International, v. 22-23, p. 141-171, https://doi.org/10.1016/1040-6182(94)90010-8.

Harbert, R.S., and Nixon, K.C., 2015, Climate reconstruction analysis using coexistence likelihood estimation (CRACLE): A method for the estimation of climate using vegetation: American Journal of Botany, v. 102, p. 1277-1289, https://doi.org/10.3732/ajb.1400500.

Haywood, A.M., Dowsett, H.J., Valdes, P.J., Lunt, D.J., Francis, J.E., and Sellwood, B.W., 2009, Introduction. Pliocene climate, processes and problems: Philosophical Transactions of the Royal Society A, v. 367, p. 3-17, https://doi.org/10.1098/ rsta.2008.0205.

Heer, O., 1868, Die Fossile Flora der Polarländer, die in Nordgronland, auf der Melville-Insel, im Banksland, am Mackenzie, in Island und in Spitzbergen entdeckten fossilen Pflanzen: Druck und Verlag von Friedrich Schulthess, Zurich, p. $1-192$.

Hidy, A.J., Gosse, J.C., Froese, D.G., Bond, J.D., and Rood, D.H., 2013, A latest Pliocene age for the earliest and most extensive Cordilleran Ice Sheet in northwestern Canada: Quaternary Science Reviews, v. 61, p. 77-84, https://doi.org/ 10.1016/i.quascirev.2012.11.009.

Hills, L.V., 1975, Late Tertiary floras Arctic Canada: An interpretation: Proceedings of Circumpolar Conference on Northern Ecology, National Research Council of Canada, p I(63)-I(71)

Hutchison, J.H., and Harington, C.R., 2002, A peculiar new fossil shrew (Lipotyphla, Soricidae) from the High Arctic of Canada: Canadian Journal of Earth Sciences, v. 39, p. 439-443, https://doi.org/10.1139/e01-078.

Lakeman, T.R., Gosse, J.C., Blasco, S., Braschi, L.C., and Rybczynski, N., 2014, Reconstructing the nature of Pliocene-Pleistocene landscape dynamics in the Canadian Arctic from the age and architecture of the Iperk Fm. in the Beaufort Sea (Abstract): 'Past Gateways' First International Conference and Workshop, 2013, Abstracts, v. 1, p. 44.

Manion, P., 2017, Lithospheric flexural controls on landscape evolution during deposition and incision of the Beaufort Formation, western Canadian Arctic: Unpublished Honours Thesis, Dalhousie University, Halifax, NS, 81 p.

Martínez-Botí, M.A., Foster, G.L., Chalk, T.B., Rohling, E.J., Sexton, P.F., Lunt, D.J., Pancost, R.D., Badger, M.P.S., and Schmidt, D.N., 2015, Plio-Pleistocene climate sensitivity evaluated using high-resolution $\mathrm{CO}_{2}$ records: Nature, v. 518, p. 49-54, https://doi.org/10.1038/nature14145.

Masson-Delmotte, V., Schulz, M., Abe-Ouchi, A., Beer, J., Ganopolski, A., González Rouco, J.F., Jansen, E., Lambeck, K., Luterbacher, J., Naish, T., Osborn, T., OttoBliesner, B., Quinn, T., Ramesh, R., Rojas, M., Shao, X., and Timmermann, A., 2013, Information from Paleoclimate Archives, in Stocker, T.F., Qin, D., Plattner, G.-K., Tignor, M., Allen, S.K., Boschung, J., Nauels, A., Xia, Y., Bex, V., and Midgley, P.M., eds., Climate Change 2013: The Physical Science Basis. Contribution of Working Group I to the Fifth Assessment Report of the Intergovernmental Panel on Climate Change: Cambridge University Press, Cambridge, UK and New York, NY, USA, p. 383-464, https://doi.org/10.1017/CBO9781107415324.013.

Matthews Jr., J.V., 1987, Plant macrofossils from the Neogene Beaufort Formation on Banks and Meighen Islands, District of Franklin: Geological Survey of Cana- da, Current Research, Part A, Paper 87-1A, p. 73-87.

Matthews Jr., J.V., and Fyles, J.G., 2000, Late Tertiary plant and arthropod fossils from the High Terrace Sediments on the Fosheim Peninsula of Ellesmere Island (Northwest Territories, District of Franklin): Geological Survey of Canada Bulletin, v. 529 , p. $295-317$

Matthews Jr., J.V., and Ovenden, L.E., 1990, Late Tertiary plant macrofossils from localities in Arctic/Subarctic North America: a review of the data: Arctic, v. 43, p 364-392, https://doi.org/10.14430/arctic1631.

McNeil, D., Duk-Rodkin, A., Dixon, J., Dietrich, J., White, J., Miller, K., and Issler, D., 2001, Sequence stratigraphy, biotic change, ${ }^{87} \mathrm{Sr} /{ }^{86} \mathrm{Sr}$ record, paleoclimatic history, and sedimentation rate change across a regional late Cenozoic unconformity in Arctic Canada: Canadian Journal of Earth Sciences, v. 38, p. 309-331, https://doi.org/10.1139/e00-098.

Mitchell, W.T., Rybczynski, N., Schröder-Adams, C., Hamilton, P.B., Smith, R., and Douglas, M., 2016, Stratigraphic and paleoenvironmental reconstruction of a Mid-Pliocene fossil site in the High Arctic (Ellesmere Island, Nunavut): Evidence of an ancient peatland with beaver activity: Arctic, v. 69, p. 185-204, https://doi.org/10.1038/nclimate2940.

Murray, A.M., Cumbaa, S.L., Harington, C.R., Smith, G.R., and Rybczynski, N., 2009, Early Pliocene fish remains from Arctic Canada support a pre-Pleistocene dispersal of percids (Teleostei: Perciformes): Canadian Journal of Earth Sciences, v. 46, p. 557-570, https://doi.org/10.1139/E09-037.

Pagani, M., Liu, Z., LaRiviere, J., and Ravelo, A.C., 2010, High Earth-system climate sensitivity determined from Pliocene carbon dioxide concentrations: Nature Geoscience, v. 3, p. 27-30, https://doi.org/10.1038/ngeo724.

Preece, S.J., Westgate, J.A., Froese, D.G., Pearce, N.J.G., and Perkins, W.T., 2011, A catalogue of late Cenozoic tephra beds in the Klondike goldfields and adjacent areas, Yukon Territory. Yukon Geological Survey Contribution 010: Canadian Journal of Earth Sciences, v. 48, p. 1386-1418, https://doi.org/10.1139/e10-110.

Roth-Nebelsick, A., 2005, Reconstructing atmospheric carbon dioxide with stomata: possibilities and limitations of a botanical $p \mathrm{CO}_{2}$-sensor: Trees, v. 19, p. 251-265, https://doi.org/10.1007/s00468-004-0375-2.

Rybczynski, N., Gosse, J.C., Harington, R.C., Wogelius, R.A., Hidy, A.J., and Buckley, M., 2013, Mid-Pliocene warm-period deposits in the High Arctic yield insight into camel evolution: Nature Communications, v. 4, p. 1550, https://doi.org/10.1038/ ncomms 2516 .

Salzmann, U., Dolan, A.M., Haywood, A.M., Chan, W.-L., Voss, J., Hill, D.J., AbeOuchi, A., Otto-Bliesner, B., Bragg, F.J., Chandler, M.A., Contoux, C., Dowsett, H.J., Jost, A., Kamae, Y., Lohmann, G., Lunt, D.J., Pickering, S.J., Pound, M.J., Ramstein, G., Rosenbloom, N.A., Sohl, L., Stepanek, C., Ueda, H., and Zhang, Z. 2013, Challenges in quantifying Pliocene terrestrial warming revealed by datamodel discord: Nature Climate Change, v. 3, p. 969-974, https://doi.org/ $10.1038 /$ nclimate2008

Seki, O., Foster, G.L., Schmidt, D.N., Mackensen, A., Kawamura, K., and Pancost, R.D., 2010, Alkenone and boron-based Pliocene $p \mathrm{CO}_{2}$ records: Earth and Planetary Science Letters, v. 292, p. 201-211, https://doi.org/10.1016/ j.epsl.2010.01.037.

Tedford, R.H., and Harington, C.R., 2003, An Arctic mammal fauna from the Early Pliocene of North America: Nature, v. 425, p. 388-390, https://doi.org/ 10.1038 /nature 01892

Tozer, E.T., 1956, Geological reconnaissance, Prince Patrick, Eglington and western Melville Islands, Arctic Archipelago, Northwest Territories: Geological Survey of Canada, Paper 55-5, p. 1-32.

Tozer, E.T., and Thorsteinsson, R., 1964, Western Queen Elizabeth Islands, Arctic Archipelago: Geological Survey of Canada, Memoir 332. Ottawa, p. 1-242.

Trettin, H.P., 1989, The Arctic Islands, in Bally, A.W., and Palmer, A.R., eds., The Geology of North America-An Overview: DNAG Volume A, Geological Society of America, p. 349-370, https://doi.org/10.1130/DNAG-GNA-A.349.

Xue, K., Yuan, M.M., Shi, Z.J., Qin, Y., Deng, Y., Cheng, L., Wu, L., He, Z., Van Nostrand, J., Bracho, R., Natali, S., Schuur, E.A.G., Lou, C., Konstantinidis, K.T., Wang, Q., Cole, J.R., Tiedje, J.M., Luo, Y., and Zhou, J., 2016, Tundra soil carbon is vulnerable to rapid microbial decomposition under climate warming: Nature Climate Change, v. 6, p. 595-600, https://doi.org/ 10.1038/nclimate2940.

Yang, J., Spicer, R., Spicer, T., and Li, C.-S., 2011, 'CLAMP Online': a new web-based palaeoclimate tool and its application to the terrestrial Paleogene and Neogene of North America: Palaeobiodiversity and Palaeoenvironments, v. 91, p. 163-183, https://doi.org/10.1007/s12549-011-0056-2.

\section{Received November 2016 Accepted as revised March 2017}

